ADVANCE RESEARCH JOURNAL OF

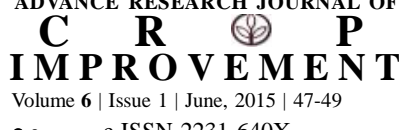

$\bullet \bullet \bullet$ e ISSN-2231-640X

DOI :

10.15740/HAS/ARJCI/6.1/47-49

Visit us: www.researchjournal.co.in

\section{Authors' Info} Associated Co-author : ${ }^{1}$ Krishi Vigyan Kendra, Mangalbharti, VADODARA (GUJARAT) INDIA
Author for correspondence: C.R. PATEL

Krishi Vigyan Kendra,

Mangalbharti, VADODARA

(GUJARAT) INDIA

Email: kvkvdr@gmail.com

\title{
Application of fertilizer based on soil testing for better production of cotton
}

C.R. PATEL, K.K. SUTARIA ${ }^{1}$, M.C. BRAHMBHATT ${ }^{1}$, B.M. MEHTA ${ }^{1}$ AND M.L. PATEL $^{1}$

ABSTRACT : The field experiment was conducted on cotton during three consecutive Kharif seasons of the year 2011 to 2013 in order to develop fertilizer prescriptions for the desired yield targets with three treatments viz., farmers practice, recommended practices and soil testing based fertilizer application. For taking higher production of crop a viable approach is needed to supply the crop with nutrients that limit its production. The present study deals with this issue. In this experiment application of chemical fertilizer along with biofertilizer based on soil testing increased 15.90 per cent in economic yield than the farmers practice during all the years. The net return also showed an increase of Rs. 17732/- per ha under soil testing based fertilizer application than farmer practices during three years.

KEY WORDS : Cotton, Fertilizer application, Production, Soil testing

How to cite this paper : Patel, C.R., Sutaria, K.K., Brahmbhatt, M.C., Mehta, B.M. and Patel, M.L. (2015). Application of fertilizer based on soil testing for better production of cotton. Adv. Res. J. Crop Improv., 6 (1) : 47-49.

Paper History : Received : 31.12.2014; Accepted : 08.05.2015 